\title{
Simple-sequence repeat markers of Cattleya coccinea (Orchidaceae), an endangered species of the Brazilian Atlantic Forest
}

\author{
M. Novello ${ }^{1}$, J.F. Rodrigues ${ }^{1}$, F. Pinheiro ${ }^{2}$, G.C.X. Oliveira ${ }^{1}$, \\ E.A. Veasey $^{1}$ and S. Koehler ${ }^{3}$ \\ 'Departamento de Genética, Escola Superior de Agricultura "Luiz de Queiroz", \\ Universidade de São Paulo, Piracicaba, SP, Brasil \\ ${ }^{2}$ Instituto de Botânica de São Paulo, São Paulo, SP, Brasil \\ ${ }^{3}$ Departamento de Ciências Biológicas, Universidade Federal de São Paulo, \\ Diadema, SP, Brasil
}

Corresponding author: S. Koehler

Email: samantha.koehler@unifesp.br

Genet. Mol. Res. 12 (3): 3274-3278 (2013)

Received January 23, 2013

Accepted March 13, 2013

Published September 3, 2013

DOI http://dx.doi.org/10.4238/2013.September.3.3

\begin{abstract}
Microsatellite markers were developed for the endangered Brazilian orchid species Cattleya coccinea to describe its genetic diversity and structure and to support conservation studies. Nine microsatellite loci were isolated and characterized using an enriched genomic library. All loci are polymorphic at least in the 2 populations sampled, except for loci Cac05 and Cac09 for the Petrópolis population. The mean number of alleles per locus was 8.8 between populations. The mean values of the observed and expected heterozygosities were 0.541 (ranging from 0 to 1 ) and 0.639 (ranging from 0 to 0.9 ), respectively. Cross-amplifications were performed in 7 additional Epidendroideae species, and at least 2 loci were successful in 3 additional Cattleya species, Epidendrum secundum, and Brasiliorchis gracilis. All markers described herein will be useful in further studies evaluating the genetic diversity, population dynamics,
\end{abstract}


and conservation genetics of $C$. coccinea and related species.

Key words: Cattleya; Epidendroideae; Laeliinae; Microsatellite markers; Orchidaceae; Sophronitis

\section{INTRODUCTION}

Orchidaceae is one of the largest plant families of angiosperms, with approximately 26,000 species (WCSP, 2012). This enormous diversity is concentrated in the Neotropics, and more than 2000 species are found in Brazil (Barros et al., 2012). Cattleya coccinea Lindl., with its bright, scarlet flowers, is a well-known ornamental orchid found at medium to high elevations in the Atlantic Forest in southeastern Brazil (Fowlie, 1987). Although the Atlantic Forest biome has been reduced to less than $8 \%$ of its original area, deforestation and indiscriminate collection continue to be decisive factors in the loss of genetic diversity of natural populations (Morellato and Haddad, 2000).

Microsatellite markers are ideal for population genetic studies because they are highly polymorphic owing to expression and co-dominant multiallelism. Thus, these markers are important tools for the assessment of the effects of habitat fragmentation on the diversity, demography, and genetic structure of populations, providing crucial information to guide conservation strategies.

In this study, we report the isolation and characterization of 9 microsatellite loci for the species $C$. coccinea. These markers are the first simple-sequence repeat primers developed for this genus, which is the most ornamental among Brazilian orchids. Additionally, the developed markers were tested for cross-transferability within the subtribe Laeliinae as well as in other species of the subtribe Epidendroideae.

\section{MATERIAL AND METHODS}

Forty individuals from 2 natural populations of $C$. coccinea were sampled: 20 individuals from Petrópolis (Rio de Janeiro State, Brazil, S22 $\left.{ }^{\circ} 6^{\prime} 39^{\prime \prime}, \mathrm{W}^{\circ} 3^{\circ} 13^{\prime} 41^{\prime \prime}\right)$ and 20 individuals from São José do Barreiro (São Paulo State, Brazil, S22 ${ }^{\circ} 46^{\prime} 30^{\prime \prime}$ W4439'63"). Voucher specimens for all species/populations sampled were deposited at the herbarium of Escola Superior de Agricultura Luiz de Queiroz, University of São Paulo (Piracicaba, SP, Brazil) (Table 1).

\begin{tabular}{|c|c|c|c|}
\hline Taxon & Voucher specimen & Collection origin & Herbarium registration number \\
\hline Cattleya coccinea Lindl. & Rodrigues 761 & Petrópolis/RJ & ESA120066 \\
\hline C. coccinea Lindl. & Koehler et al. sn $(1615)^{*}$ & São José do Barreiro/SP & ESA118314 \\
\hline C. cernua (Lindl.) Van den Berg & Bicalho sn (31219)* & Jeriquara/SP & ESA119236 \\
\hline C. dayana (Rchb.f.) Van den Berg & Brólio sn $(5908)^{*}$ & Nova Friburgo/RJ & ESA118317 \\
\hline C. pumila (Hook.) Van den Berg & Bicalho sn $(5169)^{*}$ & Santana do Riacho/MG & ESA 118318 \\
\hline $\begin{array}{l}\text { Brasiliorchis gracilis (Lodd.) R.B. Singer, } \\
\text { S. Koehler, Carnevali }\end{array}$ & Bicalho sn $(114)^{*}$ & Embu-Guaçu/SP & ESA118310 \\
\hline Epidendrum secundum Jacq. & Pinheiro 637 & Ubatuba/SP & ESA119239 \\
\hline Oncidium longipes Lindl. & Bicalho sn $(6338)^{*}$ & Dourados/MS & ESA118313 \\
\hline Prosthechea vespa (Vell.) W.E. Higgins & Silva sn $(15861)^{*}$ & Porto Velho/RO & ESA118311 \\
\hline
\end{tabular}

A microsatellite-enriched genomic library was constructed using a procedure published by Billotte et al. (1999), with modifications. Genomic DNA was extracted from fresh leaves of $C$. 
coccinea using a modified cetyltrimethylammonium bromide method (Doyle and Doyle, 1987). Total DNA was digested with enzyme RsaI, and the resulting fragments were ligated to Rsa21 and $R s a 25$ adapters. For enrichment, we used (CT) and $(\mathrm{GT})_{\mathrm{n}}$ biotinylated oligonucleotide sequences linked to streptavidin-coated magnetic particles. The enriched DNA fragments were amplified and cloned using the pGEM-T Easy vector (Promega, Madison, WI, USA) and transformed into XL1-BLUE Escherichia coli competent cells (Stratagene, La Jolla, CA, USA).

A total of 192 positive clones were sequenced using the universal T7 and SP6 primer combination and a BigDye v3.1 terminator kit on an ABI3730 DNA Analyzer automated sequencer (Applied Biosystems, Foster City, CA, USA); 66 clones contained simple sequence repeats. Of these, 15 regions with sufficient quality were selected for primer design. Sequences were assembled using the SeqMan software (DNASTAR, Madison, WI, USA). The selection of sequences containing microsatellites was performed using WebSat (Martins et al., 2009). Primers were designed using PRIMER 3 (Rozen and Skaletsky, 2000).

The amplification followed the protocol of Schuelke (2000), which involves a forward primer synthesized with a 19-bp M13 tail (5'-CACGACGTTGTAAAACGAC-3'), a reverse locus-specific primer, and a universal M13 primer labeled with the fluorescent dyes FAM or HEX (Applied Biosystems). All polymerase chain reaction (PCR) amplifications were performed in $30 \mu \mathrm{L}$ volumes containing 10X PCR buffer, $1-2 \mathrm{mM} \mathrm{MgCl}_{2}, 2.5$ deoxyribonucleotide triphosphates, 0.2 pmol forward primer, 1 pmol reverse primer, 1 pmol universal M13 tail, 1 U Taq DNA polymerase, and $1 \mu \mathrm{L}$ DNA template (10-20 ng). A touchdown cycling program was used with thermal conditions as follows: $95^{\circ} \mathrm{C}$ for $3 \mathrm{~min} ; 10$ cycles at $94^{\circ} \mathrm{C}$ for $30 \mathrm{~s}, 58^{\circ} \mathrm{C}$ decreasing to $48^{\circ} \mathrm{C}$ at $1^{\circ} \mathrm{C}$ per cycle for $30 \mathrm{~s}$, and $72^{\circ} \mathrm{C}$ for $30 \mathrm{~s} ; 40$ cycles at $94^{\circ} \mathrm{C}$ for $30 \mathrm{~s}, 48^{\circ} \mathrm{C}$ for $30 \mathrm{~s}$, and $72^{\circ} \mathrm{C}$ for $30 \mathrm{~s}$; and a final extension at $72^{\circ} \mathrm{C}$ for $20 \mathrm{~min}$. For some primers, the annealing temperature was optimized to minimize the amplification of unspecific bands. In these cases, we used the following thermal conditions: $95^{\circ} \mathrm{C}$ for $3 \mathrm{~min} ; 40$ cycles at $94^{\circ} \mathrm{C}$ for $30 \mathrm{~s}$, variable annealing temperature (Table 2) for $30 \mathrm{~s}$, and $72^{\circ} \mathrm{C}$ for $30 \mathrm{~s}$; and a final extension at $72^{\circ} \mathrm{C}$ for $10 \mathrm{~min}$.

Amplified PCR products were checked using electrophoresis on 1.5\% agarose gel stained with ethidium bromide, purified with a QIAquick ${ }^{\circledR}$ PCR Purification Kit (Invitrogen, Life Technologies, São Paulo, SP, Brazil), and sequenced. Allele sizes were estimated using GeneMarker v.1.95 (Softgenetics, State College, PA, USA). The number of alleles and observed and expected heterozygosities were calculated using Genetic Data Analysis (Lewis and Zaykin, 2001).

We also checked the transferability of the designed primers by performing cross-amplifications in 7 orchid species. We sampled 3 congeneric specimens, C. cernua (Lindl.) Van den Berg, C. dayana (Rchb.f). Van den Berg, and C. pumila (Hook) Van den Berg; 2 species belonging to the same subtribe Laeliinae, Epidendrum secundum Jacq. and Prosthechea ves$p a$ (Vell.) W.E. Higgins, and 2 of the same subfamily Epidendroideae, Brasiliorchis gracilis (Lodd.) R.B. Singer, S. Koehler and Carnevali, and Oncidium longipes Lindl. A touchdown cycling program was used for these tests following the program described above.

\section{RESULTS AND DISCUSSION}

Of the 15 designed primers, 9 were successfully amplified and used to characterize 2 natural populations of $C$. coccinea. The 6 remaining primer pairs amplified multiple bands and were excluded from further analysis. All 9 loci were polymorphic among populations, with a mean number of alleles per locus of 8.8 between populations. The number of alleles within 
populations ranged from 1 to 14 in Petrópolis and 2 to 12 in São José do Barreiro. The mean values of the observed and expected heterozygosities were 0.541 (ranging from 0 to 1 ) and 0.639 (ranging from 0 to 0.9 ), respectively (see Table 2). Low levels of heterozygosity were observed for most primers within populations, probably owing to intense habitat fragmentation. Isolation likely influenced the fixation of alleles for loci Cac08 and Cac10 in both populations analyzed.

Table 2. Characteristics of 9 microsatellite primers developed for Cattleya coccinea Lindl.

\begin{tabular}{|c|c|c|c|c|c|c|c|c|c|c|c|}
\hline \multirow[t]{2}{*}{ Locus } & \multirow[t]{2}{*}{ Sequence } & \multirow[t]{2}{*}{ Repeat } & \multirow{2}{*}{$\begin{array}{l}\text { Range size } \\
\text { (bp) }\end{array}$} & \multirow{2}{*}{$\mathrm{Ta}\left({ }^{\circ} \mathrm{C}\right)$} & \multirow[t]{2}{*}{ GeneBank } & \multicolumn{3}{|c|}{ Petrópolis } & \multicolumn{3}{|c|}{ São José do Barreiro } \\
\hline & & & & & & $N_{\mathrm{A}}$ & $H_{\mathrm{O}}$ & $H_{\mathrm{E}}$ & $N_{\mathrm{A}}$ & $H_{\mathrm{O}}$ & $H_{\mathrm{E}}$ \\
\hline $\mathrm{Cac} 01$ & $\begin{array}{l}\text { F: TACAACGCCCAATTTGAATG } \\
\text { R: CCATCATTTGCCTTTTCACA }\end{array}$ & $(\mathrm{GA})_{17}$ & 108 & TD & JQ994289 & 8 & 0.750 & 0.735 & 9 & 0.250 & 0.838 \\
\hline $\mathrm{Cac02}$ & $\begin{array}{l}\text { F: CAGGATTTCTCCTCGTGCTC } \\
\text { R: GCAGAGCGGAACAAGGATAG }\end{array}$ & $(\mathrm{AG})_{18}$ & 173 & 52 & JQ994290 & 10 & 0.600 & 0.864 & 7 & 0.150 & 0.784 \\
\hline $\mathrm{Cac} 05$ & $\begin{array}{l}\text { F: GTGCGTATTGTGAGTGGATGT } \\
\text { R: TCACGCATGCATAAGTTCAA }\end{array}$ & $(\mathrm{TG})_{10}$ & 278 & TD & JQ928870 & 1 & 0.000 & 0.000 & 3 & 0.000 & 0.477 \\
\hline $\mathrm{Cac} 08$ & $\begin{array}{l}\text { F: AGCATGCACTCACGATACAAA } \\
\text { R: GTGCATGAGTGCTTGTGTGA }\end{array}$ & $(\mathrm{CA})_{10}$ & 186 & TD & JQ994291 & 2 & 1.000 & 0.513 & 3 & 1.000 & 0.627 \\
\hline $\mathrm{Cac09}$ & $\begin{array}{l}\text { F: GGGAGGGAGGAATAGGAAGA } \\
\text { R: TGAGCTGCGATATCAAAGGA }\end{array}$ & $(\mathrm{AG})_{8}$ & 179 & TD & JQ994292 & 1 & 0.000 & 0.050 & 4 & 0.200 & 0.583 \\
\hline Cac10 & $\begin{array}{l}\text { F: GCATGAGTGCTTGTGTGAAG } \\
\text { R: TAAGCATGCACTCACGATACA }\end{array}$ & $(\mathrm{TG})_{9}$ & 184 & TD & JQ994293 & 2 & 1.000 & 0.513 & 2 & 1.000 & 0.513 \\
\hline Cac11 & $\begin{array}{l}\text { F: TCAAGGCCTGCACATAGAGA } \\
\text { R: AAGAGGAAGGCTTCGTTGC }\end{array}$ & $(\mathrm{AG})_{8}$ & 167 & TD & JQ994294 & 8 & 0.750 & 0.794 & 9 & 0.700 & 0.820 \\
\hline Cac16 & $\begin{array}{l}\text { F: AACAGGCATTTGGAGCTTTT } \\
\text { R: CCTCATTTCTCTCACCCTCTTT }\end{array}$ & $(\mathrm{AG})_{23}$ & 250 & TD & JQ994295 & 14 & 0.850 & 0.888 & 8 & 0.650 & 0.823 \\
\hline Cac18 & $\begin{array}{l}\text { F: CTGGTGAGGGAGAAGAAAAACA } \\
\text { R: CССТCTCCСTCTCTTTTCCA }\end{array}$ & $\begin{array}{c}(\mathrm{GA})_{11} \mathrm{~N} \\
(\mathrm{AG})_{26}\end{array}$ & 224 & 60 & JQ996245 & 9 & 0.150 & 0.788 & 12 & 0.650 & 0.904 \\
\hline
\end{tabular}

Eight loci had positive cross-amplification for at least 1 of the other 7 species tested. One locus (Cac09) failed to amplify in any of the additional taxa tested. Two species $(O$. longipes and $P$. vespa) resulted in no positive amplifications for any of the loci tested (Table 3). The results indicated that the 9 microsatellite reported in this study are potentially useful tools for the evaluation of genetic variation and population structure in Epidendroideae orchids.

\begin{tabular}{|c|c|c|c|c|c|c|c|c|c|}
\hline \multirow[t]{2}{*}{ Species } & \multicolumn{9}{|c|}{ Loci } \\
\hline & $\mathrm{Cac} 01$ & $\mathrm{Cac02}$ & $\mathrm{Cac} 05$ & Cac08 & Cac09 & Cac10 & Cac11 & Cac16 & Cac18 \\
\hline Cattleya pumila & + & + & - & + & - & + & + & - & + \\
\hline C. dayana & + & + & + & + & - & + & + & + & - \\
\hline C. cеrnua & + & + & - & - & - & + & - & - & - \\
\hline Oncidium longipes & - & - & - & - & - & - & - & - & - \\
\hline Prosthechea vespa & - & - & - & - & - & - & - & - & - \\
\hline Brasiliorchis gracilis & - & + & + & - & - & - & - & - & - \\
\hline Epidendrum secundum & - & + & + & - & - & - & - & - & - \\
\hline
\end{tabular}

\section{ACKNOWLEDGMENTS}

Research supported by Fundação de Amparo à Pesquisa do Estado de São Paulo 
(grants \#2006/55121-3 and \#2011/18532-3). The authors thank A.P. Souza, M. Oliveira, and C. Grando for technical support, and E. Catharino and Instituto de Botânica de São Paulo for providing specimens for study.

\section{REFERENCES}

Barros F, Vinhos F, Rodrigues VT, Barberena FVA, et al (2012). Orchidaceae in Lista de Espécies da Flora do Brasil, Jardim Botânico do Rio de Janeiro. Available at [http://floradobrasil.jbrj.gov.br/2012/FB000179]. Accessed May 18,2012

Billote N, Lagoda PJL, Risterucci AM and Baurens FC (1999). Microsatellite-enriched libraries: applied methodology for the development of SSR markers in tropical crops. Fruits 54: 277-288.

Doyle JJ and Doyle JL (1987). A rapid DNA isolation procedure for small quantities of fresh leaf tissue. Phytochem. Bull. 19: 11-15.

Fowlie JA (1987). A contribution to a monographic revision of the genus Sophronitis Lindl. Orchid Digest. 51: 15-32.

Lewis PO and Zaykin D (2001). Genetic Data Analysis: Computer Program for Theanalysis of Allelic Data. Available at [htpp://hydrodictyon.eeb.uconn.edu/people/plewis/software.php]. Accessed April 10, 2012.

Martins WS, Lucas DC, Neves KF and Bertioli DJ (2009). WebSat - a web software for microsatellite marker development. Bioinformation 3: 282-283.

Morellato LPC and Haddad CFB (2000). Introduction: the brazilian atlantic forest. Biotropica 32: 786-792.

Rozen S and Skaletsky HJ (2000). Primer 3: Bioinformatics Methods and Protocols. In: Methods in Molecular Biology (Krawatz S and Misener S, eds.) Available at [htpp://frodo.wi.mit.edu/cgibin/primer3/primer3_www.cgi]. Accessed February 15, 2011. Human Press, New Jersey, 365-386.

Schuelke M (2000). An economic method for the fluorescent labeling of PCR fragments. Nat. Biotechnol. 18: 233-234.

WCSP (2012). World Checklist of Monocotyledons. Facilitated by the Royal Botanic Gardens. Kew. Available at [http:// apps.kew.org/wcsp/wcsp/]. Accessed April 7, 2012. 